\title{
User Perspective on External Value Creation Factors in Indonesia e-Commerce
}

\author{
Sfenrianto Sfenrianto ${ }^{1}$, Hilda Oktavianni $\mathrm{JM}^{2}$, Hafid Prima Putra ${ }^{3}$, Khoerintus ${ }^{4}$ \\ Information Systems Management Department \\ BINUS Graduate Program-Master of Information Systems Management \\ Bina Nusantara University, Jakarta, Indonesia 11480
}

\begin{abstract}
Value creation is very important for the ecommerce companies in order to reach customers and increase company's value in the view of customer. Value creation mostly developed based on internal factor of the company. This statement is supported by many studies that researched on value creation from within the company. The purpose of this research is to find out customer's perspective on the external environmental factors that can affect the value creation of ecommerce companies, especially in Indonesia. This research uses primary and secondary methods in data collection. Questionnaire is used as primary research methodology in this research to gather data from e-commerce users. For the secondary method, literature reviewed from previous research and existing journals is used. The results of this research are the statements from respondents regarding external environmental factors that can be classified on 5 (five) factors: Government policy and legal, telecommunication infrastructure, financial and capital investment, physical environment, and payment system.
\end{abstract}

Keywords-External environment factors; e-commerce; user perspective; value creation

\section{INTRODUCTION}

E-commerce in Indonesia has developed and improved in many forms of business model. The development of this industry can be seen from the amount of investment in the ecommerce industry of US $\$ 2.5$ billion over the past three years It is based funding of foreign investment in Indonesia from 2015 to 2017, with 18 million customers in 2015 and is expected to increase to 119 million by 2017 [1]. The great public interest in utilizing e-commerce services is influenced by the characteristics of consumers in Indonesia, which can be classified into six, namely: Willingness to pay more for certain brands, purchasing similar goods, preference for purchasing package goods, high frequency of purchases and social media influence [2]. The increasing trend of people to buy online is causing a shift in industrial structure.

Companies are no longer determining the business model based on the conventional experience or management's will, but they must be able to adjust to the character of local community and culture. Business actors who are involved, both buyers and sellers, use the internet-based technology to carry out their transactions. The use of technology and information system in e-commerce services is featured on many online shopping platforms or e-commerce websites. Various types of business models have been produced based on a study of ecommerce in Indonesia. Most e-commerce models in Indonesia consist of five types: Business to Customer (B2C) or online marketplaces, Customer to Customer (C2C), Business to Business (B2B), flash site websites, and sales sites directly through brand websites own.

The various forms of e-commerce models require the companies to make innovation and create certain values that can provide benefits to the customers. Based on the literature studies, many researches were conducted to study the value creation in e-commerce from factors inside the company (internal) only rather than looking it from the external factors. It is a background reason for this research, which is to identify the external factors that may influence the value creation in ecommerce companies, especially in Indonesia. These external factors will certainly create more opportunities or otherwise, create potential risks for the sustainability of the business, and so business strategies are needed in dealing with the arising external factors.

The study focuses on several Indonesia's e-commerce with high visit rates, namely, Tokopedia, Lazada, Blibli, Elevenia, and Bukalapak as listed in Table I.

This research was conducted using primary data and secondary data. The primary data was obtained from the results of the questionnaire to the respondents who the e-commerce users by are asking several closed-type questions, while the secondary data was obtained through literature study or the results of previous research. Limited time, cost and location were the challenges in the research process to obtain an adequate number of respondents.

The proposed of this study is to find out customer's perspective on the external environmental factors that can shape the value creation of e-commerce companies. The results would later be analyzed and processed in order to obtain an evaluation in the form of external factors that shape value creation in e-commerce companies in Indonesia. 
TABLE I. E-COMMERCE SERVICE IN INDONESIA

\begin{tabular}{|c|c|c|c|c|c|}
\hline & \multicolumn{5}{|l|}{ E-Commerce } \\
\hline & Tokopedia & Lazada & Blibli & Elevenia & Bukalapak \\
\hline Product categories & General retail & General retail & $\begin{array}{l}\text { General merchandise with a } \\
\text { focus on electronics }\end{array}$ & General retail & General retail \\
\hline $\begin{array}{l}\text { Number of sellers }(B 2 C) \text { and/or } \\
(C 2 C)\end{array}$ & 1 million & 15,000 & 6,000 & 30,000 & 1.3 million \\
\hline Business model & $\mathrm{C} 2 \mathrm{C}, \mathrm{B} 2 \mathrm{C}$ & $\mathrm{B} 2 \mathrm{C}$ & $\mathrm{B} 2 \mathrm{C}$ & $\begin{array}{l}\mathrm{C} 2 \mathrm{C} \text {, Flash } \\
\text { sales }\end{array}$ & $\mathrm{B} 2 \mathrm{C}, \mathrm{C} 2 \mathrm{C}$ \\
\hline Monthly visits (million) & 46.5 & 51 & 25.7 & 34.6 & 28.3 \\
\hline
\end{tabular}

\section{LITERATURE REVIEW}

\section{A. E-Commerce Business Model}

From 1989 to the present, the Internet has provided many changes to many e-commerce companies in the world in managing and restructuring new systems in business to achieve their company's vision. This thinking model has flowed into a business model for each e-commerce company. In a sense, a business model is a concept to carry out the business functions of a company. The concept of business models challenges traditional theoretical assumptions about both value creation and value capture, two terms often used to describe the models [3]. However, business models are the key factors that distinguish successful and unsuccessful e-commerce companies in developing strategies to reduce costs while increasing revenue will be profitable [4]. The e-commerce company, especially in Indonesia should be considered the importance of creating innovative business models.

The biggest challenge facing most companies is not how to imitate or estimate the best e-commerce business models in their industry but how to fundamentally change the traditional business mindset [5]. Information Technology (IT), and especially web technology has great potential to enable significant innovation in business processes, products, and services of the company, leading to considerable business performance improvements [6]. In study [7] revealed that to outperform competitors in the long term, it needs to consider three main steps, including:

- provide the right resources and are also the most efficient transaction at any given time.

- renewing the peculiarities to prevent the threat of competition.

- redefining the business model effectively in accordance with the business strategy.

\section{B. E-Commerce in Indonesia}

E-commerce is a new technology that has a remarkable appearance. It can be used for novice entrepreneurs and corporate businesses. In addition, e-commerce also changes the culture of competition and business by utilizing extraordinary digital technology [8] [9]. Indonesia is one of the developing countries with the 6th largest number of internet users from 25 developing countries, namely 123 million people based on information from the Ministry of Communication and
Information of the Republic of Indonesia on November 24, 2014. The number indicates that $46.42 \%$ of the Indonesian population is connected to the internet. In other words, based on the results of research by Indonesia Investments that ecommerce (which is a group of Small Medium Enterprises) has contributed 60 percent of Indonesia's gross domestic product and created employment for nearly 108 million Indonesians [10]. This is evidence that the economic pressure is increasing annually can be both opportunity and challenge to related bodies and institutionalized in Indonesia to improve their business, legislative, and IT infrastructure for a bright future.

The e-commerce growth in Indonesia over the past five years was mainly driven by four structural changes in the industry, including [11]:

- Availability of low costs to support increased smartphone penetration.

- Creating e-commerce value to facilitate the middle class whose income tends to increase.

- Facilitating a new digital payment model that is fast and easy. Payment infrastructure must be available for customers to transact online.

- Providing direct foreign investment opportunities on ecommerce platforms, especially through significant partner relationships or joint ventures.

Data market has proved, the evolution of Indonesia's market growth by $60-70$ percent per year since provides opportunities for Indonesian e-commerce companies to their business [12]. Therefore, this momentum must be maintained and continues to be improved by both the government and ecommerce companies.

\section{Value Creation}

Study in [8] "Value Creation in E-Business" has been analyzed using a business model on 59 (fifty-nine) American and European e-businesses. The business model is defined in this research as a mechanism that describes transaction structure, content, and governance that aims to create ebusiness value. It is defined as an important value for the exploitation of the company's business opportunities. Based on this research, four important values are found, namely: novelty, complementarity, efficiency, and locking. This value is an important factor in value creation for e-commerce. 
The study "E-commerce developments and strategies for value creation: The case of Russia" added ease of use, accessibility, ease of search and trust in their source of value creation with efficiency, lock-in, complementarities and novelty along together as interactivity of value creation [4]. The study labeled it as Internal value drivers. Each eight of ecommerce value driver are given as to how some Russian firms are using e-commerce to create value by including these drivers in their business models. External environment also mentioned in this study, see sub section $D$ for a general representation of these models.

In addition, value creation itself is not only to exploit business opportunities but can act as a business model strategy that gets financial benefits. To investigate the e-commerce business model that is beneficial, one of which is in Poland which includes 150 business marketplaces, customer to customer, and customer to business [13]. The results of this study are statistically significant value creation business models affect the sales ratio. The results also show that three important factors in value creation (efficiency, novelty, and locking) are closely related to financial performance.

\section{External Environment Factors}

From the results of study in [4], stated that external environment factors play an important role in determining how e-commerce produces value creation. The success of an ecommerce company in Russia, is an e-commerce company that has a business model that pays attention to external environment factors and value drivers to increase efficiency in transactions and revenues by reducing transaction costs and increasing social perception. External factors that can form business strategies for e-commerce companies are financial resources; availability of computers and internet connections; telecommunications infrastructure; computer programming resources; external physical environment; law, government, political and economic stability; internet security and payment system.

In the previous research conducted in [14] using PEST (Political, Economic, Social and Technological) analysis as an external environment factor that would generate opportunities, threats and business implications for e-commerce. External environment factors must be considered before carrying out the process of formulating the company's strategy so that it can avoid undesirable strategies and increase the likelihood of the company to growth. External factors are Governmental environment; Domestic politics; International politic; Economic development; Arid industry sector policies; Regional economy; Monetary and fiscal policies; Social environment; Cultural environment; Demographic environment; Natural environment; Processing technology; Information technology.

\section{RESEARCH METHODOLOGY}

This research had two phases in this methodology. First, by doing systematic literature review from others reliable journals as references to find external value creation factors based on external environment according e-commerce in Indonesia. Second methodology in this research is questionnaires, the questionnaires distributed to respondents where they had used e-commerce in Indonesia. The proposed of this questionnaire is to find user's perspective from external environment in Indonesia's e-commerce. With this approach the relationship between concepts expressed in the data and drawing conclusions from the evidence [15]. Environment factors were defined in this research as factors that shape the development of e-commerce. External environment factors in previous study [4] are used as references in choosing external factors that have some similarity between Indonesia and Russia.

When doing research, questionnaire has been delivered to random respondents that been used e-commerce in Indonesia. The total respondents are 139 people. Many of them are person above poverty line. The successful of emerging e-commerce cannot be separated from people with good financial resources as its customers. This questionnaire filled with what respondents' opinions about external environment when using e-commerce. Likert scale is used through this questionnaire; by using score range (1 to 5) from strongly disagree to strongly agree. After data were obtained from respondents, the data will be analyzed and make conclusion from it. Analysis about the data will produce the prospective user how external environment factors in Indonesia affect value creation within ecommerce.

Questionnaire is the preferred method of this research due to some reasons. One of the reasons is because it is relatively high response instead of interview method which could difficulty in conduct face-to-face and low response rates in the obtained data. The effort of delivered questionnaire occurred in 2018. It took two days to collect the result. The questionnaire itself using Indonesian, if using English as its questions, respondents were difficult to understand about questions. It because most respondent unable to understand English. Furthermore, by this questionnaire will able to make comparison regarding perspective between one respondent to others.

\section{FINDING AND DISCUSSION}

\section{A. Questionnaire Results}

Based on 139 data were collected of which then studied and analyzed one at a time to find out the attitudes and behavior of respondents in responding to the external factors that can shape the value creation in e-commerce companies in Indonesia. As an overview, there are 2 (two) out of 139 respondents were not using e-commerce due to their preference in conventional transaction instead of digital transaction, therefore only 137 respondents calculating in this research.

An analysis was carried out to identify the 137 respondent's status. Fig. 1 presents, most of the respondents are over years old $43.9 \%$ and working as private employees $63.3 \%$, with background education is undergraduate or bachelor's degree $66.2 \%$.

The next information that can be seen is that most ecommerce sites that were used or visited by the respondents are Tokopedia (123 visited) followed by Lazada ( 89 visited) with the percentage as shown in Fig. 2. 


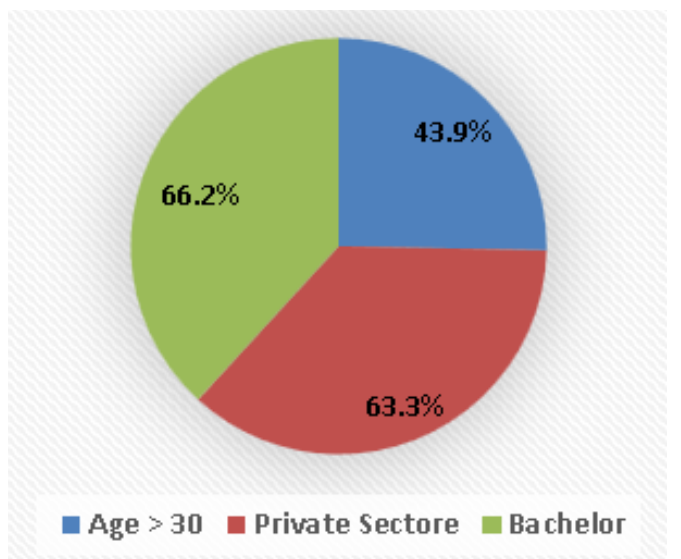

Fig. 1. General Information of Respondents.

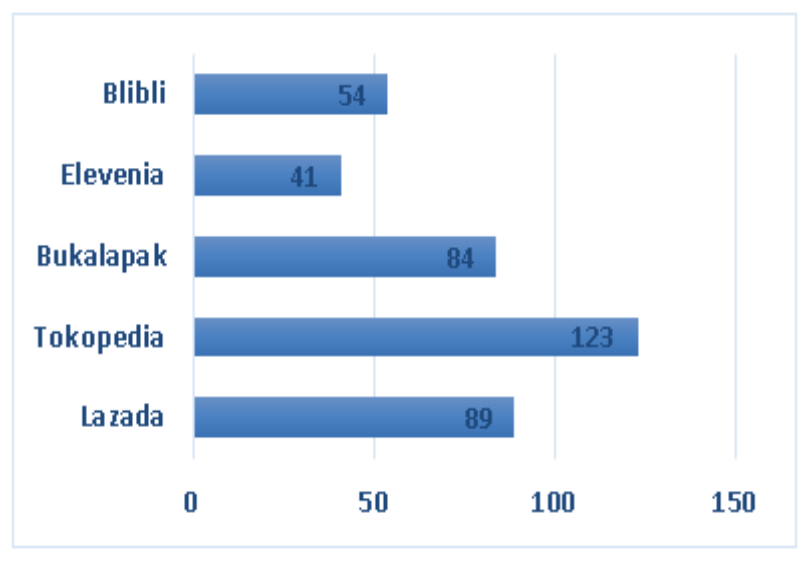

Fig. 2. E-Commerce Sites used / Visited.

TABLE II. QUESTIONER RESULTS

\begin{tabular}{|c|c|c|c|}
\hline \multirow{2}{*}{ External Environment } & \multicolumn{3}{|c|}{ Response (\%) } \\
\hline & $S D+D$ & $N$ & $S A+A$ \\
\hline \multicolumn{4}{|c|}{ Government Policy and Legal } \\
\hline $\begin{array}{l}\text { Legal certainty in e-commerce } \\
\text { transaction }\end{array}$ & 7 & 21 & 72 \\
\hline $\begin{array}{l}\text { The tax impose for e-commerce } \\
\text { business }\end{array}$ & 26 & 33 & 41 \\
\hline \multicolumn{4}{|c|}{ Finance and Capital Investment } \\
\hline $\begin{array}{l}\text { Foreign investment influencing user } \\
\text { visit e-commerce sites }\end{array}$ & 31 & 47 & 22 \\
\hline $\begin{array}{l}\text { Customer preference using } e \text { - } \\
\text { commerce mostly when receive } \\
\text { salary }\end{array}$ & 28 & 36 & 36 \\
\hline $\begin{array}{l}\text { Customer preference most using e- } \\
\text { commerce at national holiday }\end{array}$ & 27 & 31 & 42 \\
\hline $\begin{array}{l}\text { Customer preference using } \\
\text { installment payment method }\end{array}$ & 48 & 26 & 26 \\
\hline \multicolumn{4}{|l|}{ Physical Environment } \\
\hline $\begin{array}{l}\text { The distance of the shopping store } \\
\text { from user location }\end{array}$ & 37 & 28 & 35 \\
\hline $\begin{array}{l}\text { The traffic route to the shopping } \\
\text { store }\end{array}$ & 24 & 26 & 50 \\
\hline
\end{tabular}

Then, the next analysis process is to look into the answers of respondents regarding the external factors which become the focus of this research. The results of answers using the Likert method will be classified according to the questions and the most answers given by the respondent. The following is summary of the answers to questions using the Likert method based on the most given answers by 137 respondents which is classified into: Agree (A), Disagree (D), Neutral (N), and Strongly Agree (SA) responses. Table II presents the questioner results of government policy and legal, financial and capital investment, and physical environment. Meanwhile, the results of the telecommunication infrastructure and payment system will be described in section $\mathrm{D}$ and $\mathrm{F}$.

\section{B. Government Policy and Legal Factors}

As a means of selling and buying products by digital, Ecommerce transactions in Indonesia must comply with both Law No. 7 of 2014 concerning Trade and Law No. 11 of 2008 related to Electronic Information and Transactions - ITE. The existence of regulations that provide legal certainty for users and e-commerce company will increase the consumers trust in online transactions. It is one of the expected concerns of the respondents with $72 \%$ of respondents answering strongly agree and agree to legal certainty to protect consumers. The significance of these regulations makes the e-commerce company to be careful in creating their systems and also when maintaining the quality of products offered. As the result, ecommerce business company can compete in a healthy manner when offering new innovations in reaching the customers without violating the existing regulations.

The development of e-commerce business in Indonesia also indirectly changes the business behavior from conventional to the digital one. The digital transaction draws attention of the government to impose taxes on the sale of goods/services in ecommerce transaction. This tax imposition also applies in many countries other than Indonesia. This is the basis of this research, that whether the application of e-commerce tax will affect the users of online services or not. Most respondents answered neutral (33\%) in responding to this tax regulation. However, the proportional most answer was $41 \%$ people answered Strongly Agree and Agree. Hence, the tax regulations that will be applied should be a concern for ecommerce businesses to implement their business strategies, especially in planning product costs and prices.

\section{Financial Factors and Capital Investment}

Ownership of foreign shares in e-commerce companies is one of the alternative financing in developing a business. The large population of Indonesia as well as the increasing interest of the public in using online transactions has attracted many foreign investors in e-commerce business in Indonesia. One of the widely known foreign investors in Asia is Alibaba group. This company has made its investment in the development of Tokopedia and Lazada in Indonesia. This research also attempts to find out whether the foreign investors are one indication of users for visiting the e-commerce sites. A number of $47 \%$ respondents answered Neutral, while it is if measured proportionally, the respondents who answered Disagree were more than those who answered Agree. Accordingly, the respondents generally feel that they do not need to know much 
about who the investors behind the e-commerce are. This condition certainly will give benefits and opportunities for the local investors to be able to develop e-commerce in their country and compete with the foreign e-commerce sites.

Another object of this research in financial factors is the availability of fund of the consumers in conducting online transactions. For those who have stable jobs, their availability of funds is when they receive salary, as companies in Indonesia commonly pay employee salary at the end of the month. This phenomenon turns out to be a regular activity in using the ecommerce. Based on the proportional of data obtained, $36 \%$ respondents answered Strongly Agree and Agree. This consumer behavior will surely affect the implementation of a good operational management for e-commerce companies at the end of the month.

Other condition is related to national holiday which offer many discount or sale to the e-commerce customer. Total of 42\% respondent Strongly Agree and Agree to using ecommerce at the national holiday. This condition could be one of consideration for e-commerce company to provide any promotion for the customer. Customer behavior that tends to make transactions during the payday also follows the payment system behavior. As many as $48 \%$ respondents said they did not agree to make installment payments, while those who agree to use credit cards were only 19 respondents. It can be assumed that e-commerce customers tend to make transactions in cash and avoid paying the interest from credit or installment method.

\section{Telecommunication Infrastructure Factor}

Factors of telecommunication facilities availability such as the Internet are very influential for a smooth operation of the Indonesian e-commerce. Based on questionnaire result, the price $(34 \%)$ has proved that an important factor according to respondents in e-commerce transactions, in addition to provider and internet network about 31\% (see Fig. 3). Therefore, telecommunication business company are expected to be able to develop an effective and efficient quality of systems both in maintenance and repair for them to provide economical prices for the customers in transactions. Ecommerce Company may also consider using a telecommunication provider that offers data connection speeds at a competitive price.

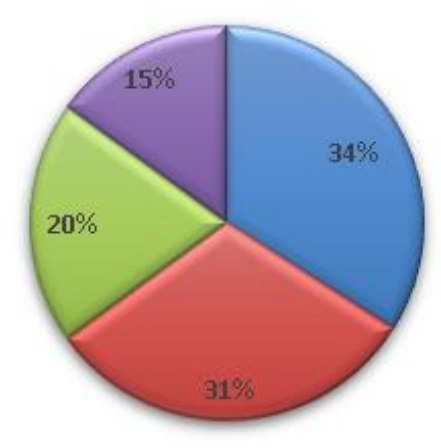

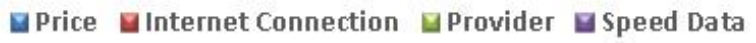

Fig. 3. The Most Important Factor of Telecommunitaion in E-Commerce.

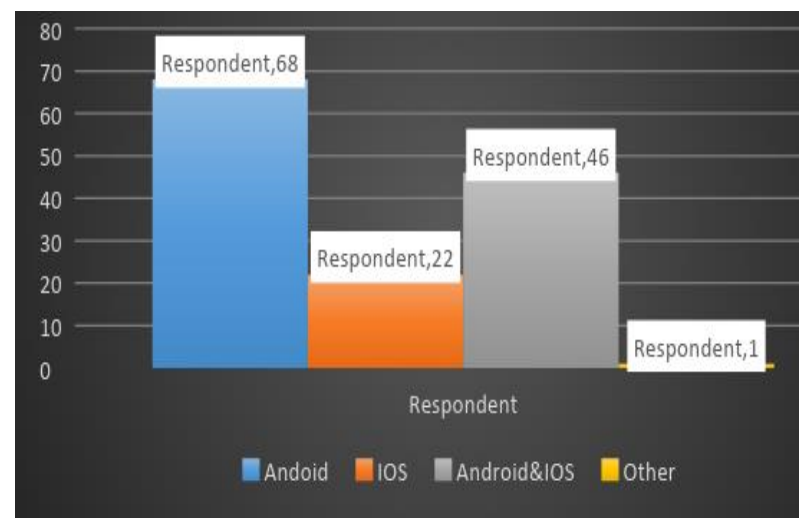

Fig. 4. The Result of Operation System used in E-Commerce.

Other factor of this research is the operational system used in transactions. As presented in the Fig. 4, a total of 68 respondents answered that they use Android system for online transactions and followed by Android \& IOS about 46 respondents. Both operational systems are in great demand today, especially for Indonesian consumers. The convenience, speed and economical price should be considered by the operating system developers in developing their newest products.

\section{E. Physical Environment}

The physical environmental factor in this study is the movement of people from one place to another. Other place in this case is the shopping centers or shops which are physically existing. Consumers behavior who made online transactions, indeed are not directly influenced by the distance of their location to the conventional shopping centers. As many as 38 respondents stated Neutral, while the proportion of the answer in category Disagree and Strongly Disagree are 51 people and the respondents who answered Agree and Strongly Agree are 48 people. Although the majority answered Disagree, but with a close difference in results, it can be observed that the existence of conventional stores that are far from the location of consumers will affect the number of store visits and therefore, the consumers turn to e-commerce.

Other things related to this physical environment can also be observed from route condition to the shopping center. Relatively congested roads in Indonesia, especially in the capital city of Jakarta, has made the consumers reluctant to go to the shopping centers/shops and so that they chose to shop online instead. Based on the results of the questionnaire it was found that $28.5 \%$ of the respondents answered Strongly Agree that traffic jams were the reason for e-commerce transactions.

\section{F. Payment Method}

Many payment systems can be made on e-commerce starting from internet banking, ATMs, through physical outlets or by Cash on Delivery (COD). E-commerce business company can also complete their payment method though payment gateway system to various merchants. From the results of the respondent's answers, it was found that $70.8 \%$ of respondents used transfer payment via internet banking in their transactions. Finally, guarantee of trust and success of the transaction through internet banking is an important issue for the consumers in making payments. E-commerce business 
company may cooperate with financial institutions such as Banks or companies providing electronic payment instruments that guarantees convenience and timeliness of payments.

\section{CONCLUSION AND FUtURE RESEARCH}

This study aimed to find out the statements of respondents about external environmental factors that could be used as suggestion to the e-commerce companies in developing their companies, especially in Indonesia. External factor has proved that Government policy and legal, telecommunication infrastructure, financial and capital investment, physical environment, and payment system shape the value creation of e-commerce companies in Indonesia. The presence of this study expects readers and e-commerce in Indonesia to know that external environmental factors also influence the value creation in determining the company's strategy when facing environmental changes from outside the company. However, this study only looked at e-commerce in Indonesia namely, Elevenia, Lazada, Blibli, Tokopedia and Bukalapak, Elevenia, so these findings may not refer to e-commerce in other countries.

Further research is needed to discuss these external environmental factors based on the conditions of the area or the environment of each user. For the researcher, they can use this study as references to see the important role of external factors that can affect value creation of e-commerce.

\section{REFERENCES}

[1] Anandan, R., Sipahimalani, R., Bharadwaj, A., Jhangiani, J., Kim, D., \& Ramesh, S. (2016). Trends \& Insights, Finance \& Banking.

[2] Suwastoyo, B. (2013). Retailers Eye Indonesia as Next Big Market. Jakarta Globe.

[3] Massa, L., Tucci, C. L., \& Afuah, A. (2017). A critical assessment of business model research. Academy of Management Annals, 11(1), 73104.
[4] Rachel, R., Doern, \& Carl, F.F. (2006). E-commerce developments and strategies for value creation: The case of Russia. Journal of World Business, 41, 315-327.

[5] Ho, J. C., Tseng, F. M., \& Lee, C. S. (2011, May). Service business model innovation: A Conceptual Model and a Framework for Management Consulting. In 2011 International Joint Conference on Service Sciences (pp. 247-251). IEEE.

[6] Reim, W., Parida, V., \& Örtqvist, D. (2015). Product-Service Systems (PSS) business models and tactics-a systematic literature review. Journal of Cleaner Production, 97, 61-75.

[7] Shakina, E., \& Barajas, A. (2015). Intangible-intensive profile of a company: the key to outperforming. Journal of Intellectual Capital, 16(4), 721-741.

[8] Amit, R., \& Zott, C. (2001). Value creation in e-business. Strategic management journal, 22(6-7), 493-520.

[9] Zott, C., Amit, R., \& Massa, L. (2011). The business model: recent developments and future research. Journal of management, 37(4), 10191042.

[10] Pangestu, M., \& Dewi, G. (2017). 13 Indonesia and the digital economy: creative destruction, opportunities and challenges. Digital Indonesia: Connectivity and Divergence, 227.

[11] Arinalhaq, F., \& Widyanti, A. (2019, March). The Role of National Culture on the Design and Usability of E-Commerce Websites: An Indonesian Case. In Journal of Physics: Conference Series (Vol. 1175, No. 1, p. 012192). IOP Publishing.

[12] Tambunan, T., \& Busnetti, I. (2018). Small Business Use of the Internet: Findings from Indonesia. Asian Journal of Agricultural Extension, Economics \& Sociology, 1-15.

[13] Zaborek, Piotr, Doligalski, T., \& Sysko-Romańczuk, S. (2016). Value Creation in E-Business as a Driver of Financial Performance: Investigating Business Models of Polish Internet Companies. Przedsiębiorstwo we współczesnej gospodarce-teoria i praktyka, 4, 101113.

[14] Aribawa, D. (2016). E-Commerce Strategic Business Environment Analysis in Indonesia. International Journal of Economics and Financial Issues, 6(6S), 130-134.

[15] Grix, J. (2004). The foundations of research: a student's guide. Macmillan International Higher Education. 